\title{
Ambient bioaerosol distribution and associated health risks at a high traffic density junction at Dehradun city, India
}

\author{
Sandeep Madhwal • Vignesh Prabhu • Sangeeta \\ Sundriyal • Vijay Shridhar (D)
}

Received: 28 March 2019 / Accepted: 11 February 2020 /Published online: 22 February 2020

(C) Springer Nature Switzerland AG 2020

\begin{abstract}
Traffic junctions are one of the crowded places where commuters are at high risk of developing respiratory infections, due to their greater exposure to airborne and human transmitted microbial pathogens. An airborne bioaerosol assessment study was carried out at a high traffic density junction focusing on their concentration, contribution in respirable particulate matter (PM), and factors influencing the distribution and microbial diversity. Andersen six-stage viable cascade impactor and a wide-range aerosol spectrometer were used for microbial and particulate matter measurements, respectively. Statistical analysis was conducted to evaluate the relationship between bioaerosol concentration, vehicular count, PM concentration, and meteorological parameters. The mean bacteria concentration (1962.95 $\pm 651.85 \mathrm{CFU} / \mathrm{m}^{3}$ ) was significantly different than fungi $\left(1118.95 \pm 428.34 \mathrm{CFU} / \mathrm{m}^{3}\right)(p<0.05)$. The temporal distribution showed maximum concentration for bacteria and fungi during monsoon and postmonsoon seasons, respectively. In terms of bioaerosol loading, a considerable fraction of fungi $(3.25 \%)$ and bacteria $(5.65 \%)$ contributed to the total airborne PM. Most abundant bioaerosols were Aspergillus (27.58\%),
\end{abstract}

Electronic supplementary material The online version of this article (https://doi.org/10.1007/s10661-020-8158-9) contains supplementary material, which is available to authorized users.

S. Madhwal $\cdot$ V. Prabhu $\cdot$ S. Sundriyal $\cdot$ V. Shridhar $(\triangle)$ Environmental Pollution Assessment Laboratory, School of Environment \& Natural Resources, Doon University, Dehradun, Uttarakhand 248001, India

e-mail: vs@doonuniversity.ac.in
Penicillium (23\%), and Cladosporium (14.05\%) (fungi), and Micrococcus (25.73\%), Staphylococcus (17.98\%), and Bacillus (13.8\%) (bacteria). Trafficinduced roadside soil resuspension and microbial aerosolizations from the human body were identified as the chief sources of bioaerosol emissions. The risk of lower respiratory tract infections caused by anthroponotic (human transmitted) transfer of bacterial pathogens is very high. The results of the study can be used to trace sources of microbial mediated communicable diseases, and to recommend appropriate safety measures to avoid pathogenic bioaerosol exposure.

Keywords Bioaerosols · Particulate matter P Particle size distribution $\cdot$ Vehicle count . Wide range aerosol spectrometer

\section{Introduction}

Bioaerosols are the ubiquitously distributed suspended airborne particles of biological origin (bacteria, viruses, fungi, toxins, pollen, etc.) (Lee 2011). A wide range of factors affect their distribution, including meteorological conditions (Erkara et al. 2008; Jones and Harrison 2004), type of surrounding vegetation (Pepeljnjak and Šegvić 2003), bioaerosol size (Fang et al. 2008), nutrient availability (Chi and Li 2007), microbe-particle association (Després et al. 2012), bioaerosol age (Li et al. 2015), human activities (Abdel Hameed et al. 2009), etc. The adverse effects of bioaerosols have been observed in humans as well as in animals (Millner 2009). 
Exposure to bioaerosols containing pathogenic species of microorganisms such as Aspergillus, Penicillium, Rhizopus, Curvularia, Alternaria, Staphylococcus, Pseudomonas, and Enterococcus have been associated with a range of human diseases (Patil and Kakde 2017; Abdel Hameed et al. 2009; Hurtado et al. 2014). Some of the respiratory health problems caused by bioaerosol exposure are asthma (Dales et al. 2004), bronchial hyperactivity (Raisi et al. 2013) allergic rhinitis (Fung and Hughson 2010), and chronic obstructive pulmonary disease (COPD) (Matheson et al. 2005) etc.

Different environmental settings such as composting plants (Rashidi et al. 2017; Connor et al. 2015), open landfill sites (Patil and Kakde 2017), hospitals (Cordeiro et al. 2010), wastewater treatment plants (Michałkiewicz 2018), poultry farms (Jerez et al. 2014), swine houses (Kim et al. 2007), etc. are the sources of considerable amount of bioaerosols in the atmosphere. Even, simple human activities such as coughing, sneezing, talking, and mere breathing can induce microbial discharge from the respiratory tract (Han et al. 2013; Prussin and Marr 2015) into the ambient air. Therefore, the exposure risk of pathogenic bioaerosols is excessively high, especially in the overcrowded public spaces, such as religious places (Alananbeh et al. 2015), subway stations (Fan et al. 2017), train stations (Dong and Yao 2010), market areas, bus stations, etc. These places are also among the possible exposure hotspots for instigating bioterrorism attacks (Das and Kataria 2011).

According to "2018 Revision of World Urbanization Prospects" by United Nations Department of Economic and Social Affairs (UN DESA), the current urbanization proportion of $55 \%$ is expected to rise by $68 \%$ by the year 2050 (https://www.un.org/development/ desa/publications/). With a more rural population shifting towards urban areas, the atmospheric load of pollutants including microbial contaminants is also expected to increase significantly. In a report released by the World Health Organization (WHO 2016), Dehradun, an urbanized area in northern part of India, was listed as the 31st most polluted city in the world in terms of PM pollution (https://www.who. int/phe/health_topics/outdoorair/databases/cities/en/). A recent study at Dehradun delineated the sources and excess cancer risk of $\mathrm{PM}_{10}$ inhalation (Prabhu and Shridhar 2019). In the study, besides vehicular emissions and biomass burning, road dust resuspension was identified as the major contributor to PM pollution in the city. Another study on the size segregated PM exposure in street vendors revealed a high respirable deposition dose of PM along with increased cases of respiratoryrelated disorders among those working at commercial area than at residential area (Prabhu et al. 2019). However, the authors have highlighted the need to study bioaerosol distribution to understand the impact of airborne pollutants on human health. It is also important to note that bioaerosols can occur as agglomerates attached to suspended PM (such as soil, dust, skin flakes, sand, etc.) (Xie et al. 2018), which enhances their viability and infectivity (Iwasaka et al. 2009). This highlight the hidden risks associated with the city's exposure to pathogenic bioaerosols. Owing to these facts, it is imperative to investigate the bioaerosol load at the locations where traffic flow and chances of infection to humans are high.

Traffic junctions are important outdoor public places, presenting a dynamic environment in terms of human/ vehicular movement and gathering. Different occupational workers such as traffic police, occupants of nearby shops, eateries/restaurants; roadside workers (construction and municipal workers etc.), daily commuters (office goers, students etc.) are the most vulnerable groups exposed to bioaerosol related health risks at these sites. Therefore, in this study, we focused on monitoring the distribution characteristics of airborne cultivable bioaerosols at a high traffic density site in Dehradun, India. The objectives of the study were to (i) investigate the temporal variation of cultivable airborne fungal and bacterial aerosols, (ii) understand the bioaerosol size distribution and their percentage contribution to PM, and (iii) characterize the microbial diversity at the study site.

\section{Materials and methods}

Sampling site description

Dehradun $\left(30.31^{\circ} \mathrm{N}, 78.03^{\circ} \mathrm{E}, 650 \mathrm{~m}\right.$ amsl) has witnessed rapid urbanization since its inception as the capital city of the Himalayan state, Uttarakhand, India, in the year 2000 (Fig. 1). According to the Census of India, 2011, the population density of the city was 550 persons per square kilometer, which corresponds to an increase of $32.33 \%$ since 2001 . The city observed a huge increase in the number of registered vehicles from 37,650 in the year 2001 to $1,349,020$ in 2011 (http://ueppcb.uk.gov.in/). It is a hub for several important government and private entities including 


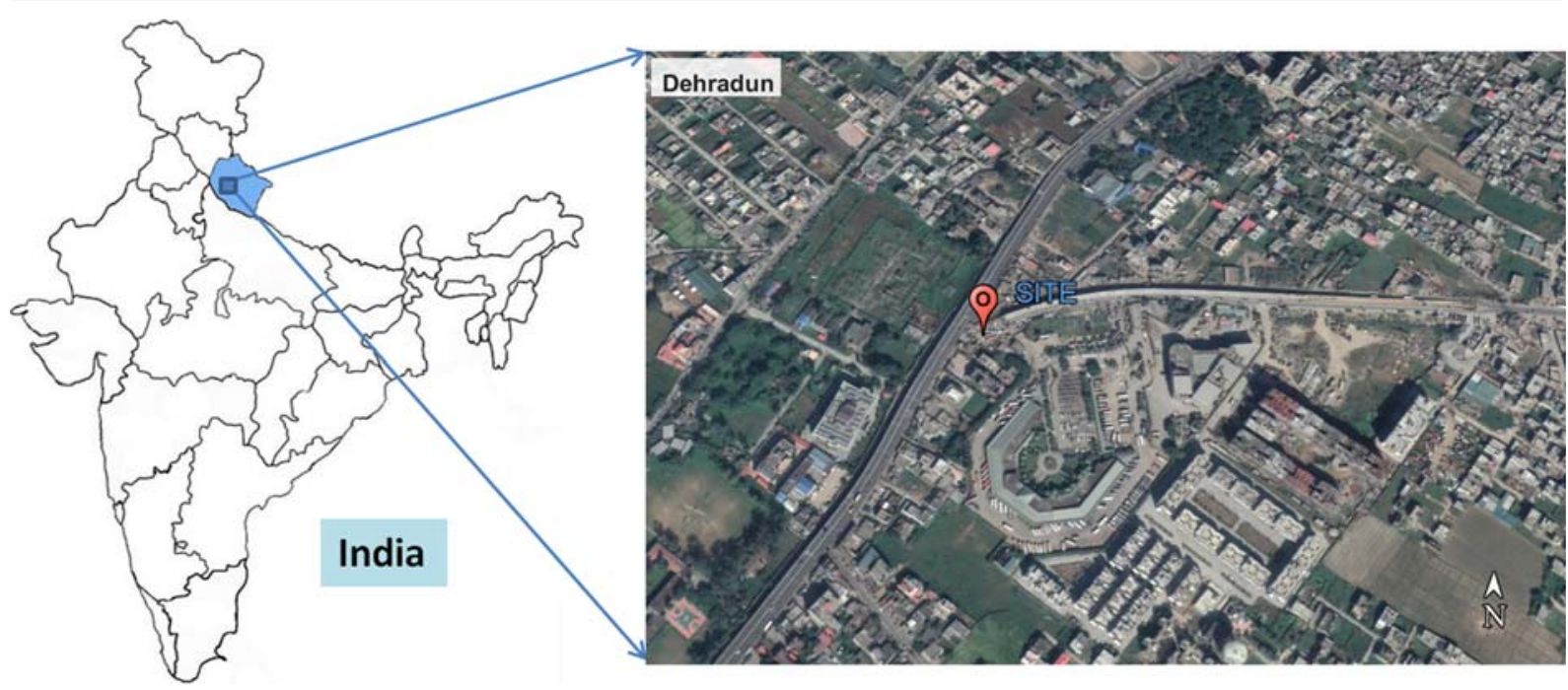

Fig. 1 Sampling site in Dehradun (source of the map: Google)

defense organizations, scientific institutions, industries, schools, colleges, universities, etc. The city is surrounded by three well-known tourist destinations namely, Haridwar (54 km South-East), Rishikesh (43 $\mathrm{km}$ South-West), and Mussoorie (38 km North), which attracts large number of visitors from different parts of the country and the world, thereby increasing its floating population.

Dehradun has a humid subtropical climate characterized by distinct seasonal variations: hot and humid summers (March to May); wet monsoons (June to $\mathrm{Au}-$ gust); post-monsoon (September to November); and mild to chilly winters (December to February). Aerosol sampling was conducted at a high traffic density junction of Inter State Bus Terminal (ISBT) at Dehradun city. ISBT was chosen as the sampling site because it is the only major bus terminal (hence, one of the most crowded public places) in Dehradun where thousands of commuters arrive every day. A pivotal three-way intersection, conjoining three National Highways witnesses frequent traffic jams in the area. The area adjoining the junction is surrounded by a cluster of roadside eateries, hotels, parking area, and a shopping mall $(\sim 100 \mathrm{~m}$ from the sampling location). Besides, the local taxis, autos, private busses, and other means of transport are also parked at this junction.

\section{Sampling methodology}

The airborne cultivable microbial samples were collected during the sampling campaign using six-stage viable
Andersen Cascade Impactors (Tisch Environmental, Cleves, OH). The sampler collects bioaerosols in the following size ranges: $0.65-1.1 \mu \mathrm{m}, 1.1-2.1 \mu \mathrm{m}, 2.1-$ $3.3 \mu \mathrm{m}, 3.3-4.7 \mu \mathrm{m}, 4.7-7.0 \mu \mathrm{m}$, and $>7.0 \mu \mathrm{m}$. These size fractions simulate the deposition pattern in different regions of the human respiratory system (Xu and Yao 2013). The flow rate of $28.3 \mathrm{~L} / \mathrm{min}$ was maintained using a calibrated dry gas meter, before each sampling event. The samplers were disinfected with $70 \%$ ethanol before each sampling event to prevent any crosscontamination (Dybwad et al. 2014). Sampling was conducted three times a day for three consecutive days, every month, for a period of 2 years (from September 2016 to August 2018). The sampling protocol was adopted from Fang et al. $(2005,2008)$. The time duration of sampling was 15 min which was selected based on the following studies. According to the guidelines for bioaerosol monitoring studies given by Tortora et al. (1989) and Jensen and Schafer (1998), time duration within which a total of 30 to 100 microbial colonies can be collected in a single petriplate should be selected as the time period for conducting bioaerosol sampling. Therefore, a pilot study was conducted prior to the sampling campaign in the study site to optimize the sampling duration. Based on the pilot study, time duration of $15 \mathrm{~min}$ was considered as the optimum time period for collecting the bioaerosol colonies. The details and the results of the pilot study are present in Appendix 1. The timings of the sampling were morning (between 07:00 HH: MM, local time, LT and 10:00 HH: MM, LT), afternoon (between 12:00 and 15:00 HH: MM, LT) 
and evening (between 16:00 and 19:00 HH: MM, LT). Three times sampling each day was conducted to cover the active exposure time of the people which represents their daily working hours (i.e., between 07:00 HH: MM, LT and 19:00 HH: MM, LT). Tryptic Soy Agar supplemented with chloramphenicol (to inhibit fungal growth) was used to collect bacterial aerosols while Sabouraud dextrose agar supplemented with cycloheximide (to inhibit bacterial growth) was used to collect fungal aerosols (Faridi et al. 2015). Overall, 216 bacterial and fungal samples were collected during the study period. Further details on the sampling methodology are provided in Appendix 2.

In parallel, a wide-range aerosol spectrometer and optical particle counter (Mini-WRAS, Model 1.371, Grimm Aerosol Technik, Germany) was used simultaneously to measure the size distributions of total airborne particles for 1 year from September 2017 to August 2018. PM mass concentration $\left(\mu \mathrm{g} / \mathrm{m}^{3}\right)$ was measured for the aerodynamic diameter less than $1 \mu \mathrm{m}$ $\left(\mathrm{PM}_{1}\right), 2.5 \mu \mathrm{m}\left(\mathrm{PM}_{2.5}\right)$, and $10 \mu \mathrm{m}\left(\mathrm{PM}_{10}\right)$, while particle number concentration (PNC, particles $/ \mathrm{m}^{3}$ ) was measured at the size range of $0.576-8.001 \mu \mathrm{m}$ (representing 17 size channels). The inlet ducts of the analyzer were cleaned every time before the sampling by passing a jet of clean compressed air. Mini WRAS operates at the flow rate of $1.2 \mathrm{~L} / \mathrm{min}$ and has a time resolution of $1 \mathrm{~min}$. In total, 108 total airborne PM samples were measured during the study period. Further details on the instrument are mentioned in Appendix 3.

Both the samplers were located at a breathing height of $1.5 \mathrm{~m}$ above ground level (AGL) maintaining a minimum distance of $1 \mathrm{~m}$ from each other and from physical barrier (Hurtado et al. 2014; Faridi et al. 2015). A section on the analytical quality control for instrument handling, sampling procedure, and data analysis is included in Appendix 4.

\section{Meteorological parameters}

The sampling campaign also included the measurement of meteorological parameters. Temperature $\left({ }^{\circ} \mathrm{C}\right)$, relative humidity $(\%)$, and wind speed $(\mathrm{m} / \mathrm{s})$ were recorded using a handheld hygro-thermo anemometer (Extech 45,160 3-IN-1). The solar radiation $\left(\mathrm{W} / \mathrm{m}^{2}\right)$ and planetary boundary layer heights (PBLH, $\mathrm{m}$ ) in 3-h intervals were acquired from the US National Oceanic and Atmospheric Administration (NOAA) READY archived Global Data Assimilation System (GDAS) (ftp://gdas- server.iarc.uaf.edu/gdas1/) meteorological data having a spatial resolution of $0.5^{\circ} \times 0.5^{\circ}$. The Air Resource Laboratory (ARL) - Hybrid Single Particle Lagrangian Integrated Trajectory (HYSPLIT) model was used to convert the data acquired from the GDAS into a readable format. The detailed procedure for calculating PBLH is described in Appendix 5. Wind direction and rainfall $(\mathrm{mm})$ data were acquired from the weather underground portal (https://www.wunderground.com).

\section{Vehicle count}

Vehicle count at the sampling site was carried out for $60 \mathrm{~min}$ (starting $45 \mathrm{~min}$ prior to each sampling). Prior counting was performed considering the fact that dust released from the ground due to vehicular/human movement may remain suspended for a considerable amount of time. The details of per hour vehicle count at the sampling site are shown in Appendix 6. It was also observed that the number of commuters arriving at the sampling site increased every time with the corresponding increase in vehicular movement. Therefore, in this study, vehicular count was also used as an indicator of human movement and associated activities.

Microbial analysis

The collected bacterial samples were incubated at $35 \pm$ $0.5^{\circ} \mathrm{C}$ temperature for $24-48 \mathrm{~h}$ (Heo et al. 2014) while fungal samples at $20-28^{\circ} \mathrm{C}$ for 3-7 days (Hoseini et al. 2013), respectively. The bioaerosol concentration was expressed as colony forming units per cubic meter of air $\left(\mathrm{CFU} / \mathrm{m}^{3}\right)$ after the standard positive-hole correction method was taken into account to statistically correct the counting (Ponce-Caballero et al. 2013). The formula used for calculating bioaerosol concentration is as follows:

\section{Bioaerosol concentration $(\mathrm{CFU} / \mathrm{m} 3)$}

$$
=\text { No.of colonies } /(\text { flow rate }(\mathrm{m} 3 / \mathrm{min}) \times \text { time }(\min ))
$$

The bacterial colonies were isolated and the pure cultures were separated based on their morphological characteristics. The isolates were identified by conducting the microscopic examination followed by biochemical tests and comparing the results obtained in Bergey's manual (Faridi et al. 2015) and Advanced 
Bacterial Identification Software (ABIS) (Rahman et al. 2017). The fungal isolates were identified using both microscopic and macroscopic examinations following the identification manual (Barnett and Hunter 2010).

\section{Statistical analysis}

One-way analysis of variance (ANOVA) was used to find whether there is significant difference in temporal variation of bioaerosols. Post hoc test was used to test the differences within each group. Pearson correlation was used to find the association between bioaerosol and PM mass concentration at different aerodynamic size $\left(\mathrm{PM}_{1}, \mathrm{PM}_{2.5}\right.$, and $\left.\mathrm{PM}_{10}\right)$, meteorological parameters (wind speed, temperature, relative humidity, and rainfall) and vehicular count. The level of significant value was set at $p<0.05$ for all the tests performed. All the calculated values were reported with the number of significant figures associated with the uncertainty of measurement.

\section{Results and discussion}

Total concentration of bioaerosols

Total bacterial and fungal concentration was obtained by averaging the sum of the concentrations of six size fractions measured during the study period. The results of the mean total bacterial and fungal bioaerosol concentration are shown in Fig. 2. Results showed that the average total bacterial concentration $\left(2.0 \times 10^{3} \pm 6.5 \times 10^{2} \mathrm{CFU} / \mathrm{m}^{3}\right)$ was significantly higher than the corresponding fungal concentration $\left(1.1 \times 10^{3} \pm 4.3 \times 10^{2} \mathrm{CFU} / \mathrm{m}^{3}\right)(p<$ $0.05)$. This can be attributed to the dominance of the bacterial population over fungi in natural environments (such as vegetation, soil, etc.) (Després et al. 2012). A strong positive correlation ( $r=0.83$, $p<0.05$ ) was observed between bacterial and fungal aerosols, indicating the similarity in factors affecting their temporal variations. Table 1 shows the comparative analysis of the sampling strategy (including different sampling durations) that has been used for monitoring bioaerosols in different countries across the globe.

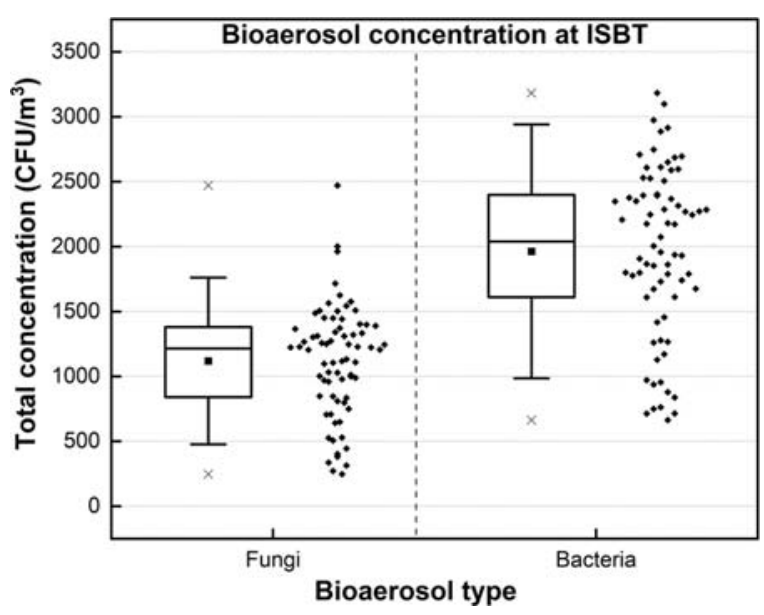

Fig. 2 Box and whisker plot showing mean total concentration of bacterial and fungal bioaerosols collected from ISBT. The lower and upper borders of the box represents 25 th and 75 th percentile, respectively. Whisker represents the standard deviation. Lower and upper cross marks represent minimum and maximum value, respectively

Temporal variation of the bioaerosols

The temporal variation of bacteria and fungi at the sampling location is shown in Fig. 3. For bacterial aerosols, concentration levels were in following order: monsoon $(\mathrm{MN})>$ post-monsoon $(\mathrm{PS})>\operatorname{summer}(\mathrm{SM})>$ winter (WN). In the case of fungal aerosols, the concentration levels followed the order: $\mathrm{PS}>\mathrm{MN}>\mathrm{SM}>\mathrm{WN}$. The results of the post hoc analysis showing significant difference in bioaerosol concentration between seasons are shown in Appendix 7. It was observed that both winter and summer season showed significant difference in bioaerosol concentrations with the rest of the seasons $(p<0.05)$. Both bacterial and fungal aerosols exhibited a similar seasonal pattern during both the sampling years.

The monthly variation for both bacteria and fungi showed that January accounted for the lowest concentration levels followed by December and February (Fig. 3). The highest bacterial concentrations were observed during August followed by July and September. On the other hand, the highest fungal concentrations were observed during September followed by October and June.

Factors affecting temporal variation

The mean vehicle count per hour, meteorological parameters (temperature, relative humidity, solar radiation, wind speed, $\mathrm{PBLH}$, and rainfall), $\mathrm{PM}_{1}, \mathrm{PM}_{2.5}$, and 
Table 1 Comparative assessment of bioaerosol monitoring in different parts of the world

\begin{tabular}{|c|c|c|c|c|c|}
\hline Country & Sampling site & Sampling protocol & $\begin{array}{l}\text { Bioaerosol } \\
\text { type }\end{array}$ & $\begin{array}{l}\text { Concentration } \\
\left(\mathrm{CFU} / \mathrm{m}^{3}\right)\end{array}$ & References \\
\hline Nigeria & Dumpsite & $\begin{array}{l}2.45 \text { min, } 1 \text { day in a week, } \\
\text { for } 13 \text { weeks }\end{array}$ & $\begin{array}{l}\text { Bacteria } \\
\text { Fungi }\end{array}$ & $\begin{array}{l}\text { Min-max }(195-2994) \\
\text { Min-max }(166-1116)\end{array}$ & Akpeimeh et al. (2019) \\
\hline Tehran & Subway stations & $\begin{array}{l}\text { Two minutes, once in every } \\
6 \text { days, } \\
\text { four consecutive months }\end{array}$ & Fungi & Min-max (14-1095) & Hoseini et al. (2013) \\
\hline Singapore & Child care centers & $\begin{array}{l}\text { Two minutes, everyday } \\
\text { between } 9 \text { am }-11 \text { am }\end{array}$ & Fungi & $\begin{array}{l}\text { Min-max } \\
\quad(1797.9-3559.8)\end{array}$ & Zuraimi et al. (2009) \\
\hline Mexico & Subway system & Ten minutes, 5 months & $\begin{array}{l}\text { Bacteria } \\
\text { Fungi }\end{array}$ & $\begin{array}{l}\text { Min- } \max (1-68) \\
\text { Min- } \max (6-80)\end{array}$ & $\begin{array}{l}\text { Hernández-Castillo et al. } \\
\text { (2014) }\end{array}$ \\
\hline Pakistan & $\begin{array}{l}\text { Urban and rural } \\
\text { area }\end{array}$ & $\begin{array}{l}\text { Two minutes afternoon timings } \\
\text { for } 3 \text { months }\end{array}$ & $\begin{array}{l}\text { Bacteria } \\
\text { Fungi }\end{array}$ & $\begin{array}{l}\text { Urban: } 2788 \\
\text { Rural: } 8031 \\
\text { Urban: } 16,416 \\
\text { Rural: } 15,790\end{array}$ & Nasir et al. (2012) \\
\hline China & $\begin{array}{l}\text { Outdoor ambient } \\
\text { air }\end{array}$ & $\begin{array}{l}\text { Ten minutes, between 8:00 h } \\
\text { and 13:00 h }\end{array}$ & $\begin{array}{l}\text { Bacteria } \\
\text { Fungi }\end{array}$ & $\begin{array}{l}\text { Min-max } \\
\quad(497.7-1736.5) \\
\text { Min-max } \\
\quad(247.6-1703.9)\end{array}$ & Li et al. (2015) \\
\hline Egypt & Industrial region & $\begin{array}{l}\text { Two to } 4 \text { min Timings between } \\
6 \text { am and } 12 \text { pm at every } \\
\text { 2-h interval, during } \\
\text { weekends, } \\
\text { two times a month for } 1 \text { year }\end{array}$ & $\begin{array}{l}\text { Bacteria } \\
\text { Fungi }\end{array}$ & $\begin{array}{l}1.414 \times 10^{3} \\
5.90 \times 10^{2}\end{array}$ & Abdel Hameed et al. (2009) \\
\hline India & University campus & $\begin{array}{l}\text { Thirty minutes, } 3 \text { days each in } \\
\text { four sites between } 11: 00 \mathrm{~h} \\
\text { and } \\
18: 00 \mathrm{~h} \text { in } 2 \text { months }\end{array}$ & $\begin{array}{l}\text { Bacteria } \\
\text { Fungi }\end{array}$ & $\begin{array}{l}\text { Min- } \max (63.6-338.8) \\
\text { Min- } \max (755-1293)\end{array}$ & Srivastava et al. (2012) \\
\hline Iran & $\begin{array}{l}\text { School dormitory } \\
\text { and } \\
\text { retirement home }\end{array}$ & $\begin{array}{l}\text { Two minutes, } 6 \text { days each } \\
\text { month } \\
\text { for a period of } 1 \text { year }\end{array}$ & Bacteria & $\begin{array}{l}\text { School dormitory: } 300 \\
\text { Retirement home: } 300\end{array}$ & Faridi et al. (2015) \\
\hline
\end{tabular}

$\mathrm{PM}_{10}$, for each season are summarized in Table 2. The values obtained for each parameter are shown after considering the number of significant figures associated with the uncertainty of measurement (explained in Appendix 8). The temporal variations in airborne microorganisms due to differences in meteorological conditions have been widely studied (Oliveira et al. 2009; Raisi et al. 2013). The correlation coefficients between different variables (bioaerosol concentration, size segregated PM concentrations, and meteorological parameters) are shown in Table 3. The relationship between bioaerosol concentrations and meteorological parameters revealed a significant positive correlation with temperature ( $r=0.70$ for bacteria and $r=0.61$ for fungi) $(p<0.05)$. This may be attributed to the stimulating effect of temperature on microbial growth and emission from the soil, as also reported by Kowalski and Pastuszka (2018). Therefore, the minimum concentration levels during winter season were due to low temperature $\left(17.0 \pm 2.7^{\circ} \mathrm{C}\right)$, while the elevated concentrations during other seasons can be attributed to the attainment of optimal temperature for microbial growth $\left(28.8 \pm 6.7^{\circ} \mathrm{C}\right)$. All the pathogens associated with mesophyllic microorganisms can grow in the optimal temperature range of $20-40{ }^{\circ} \mathrm{C}$ (Madhwal et al. 2019). Therefore, chances of infection caused by exposure to pathogenic bioaerosols are low in winter compared to other seasons.

Bacterial aerosols displayed a moderate correlation with rainfall $(r=0.42, p<0.05)$ whereas, fungal aerosols showed no significant $(p>0.05)$ correlation with rainfall. Since June is the onset month of southwest monsoonal rain, this period experienced an increase in bacterial and fungal concentration compared to that of other months. This observation can be explained in different ways: (a) Bioaerosols act as cloud condensation nuclei (Xie et al. 2018; Fröhlich-Nowoisky et al. 2016), and therefore, may precipitate from higher 
Fig. 3 Temporal variation in fungal and bacterial concentrations at a high traffic density junction (PS: postmonsoon, WN: winter, SM: summer, MS: monsoon)

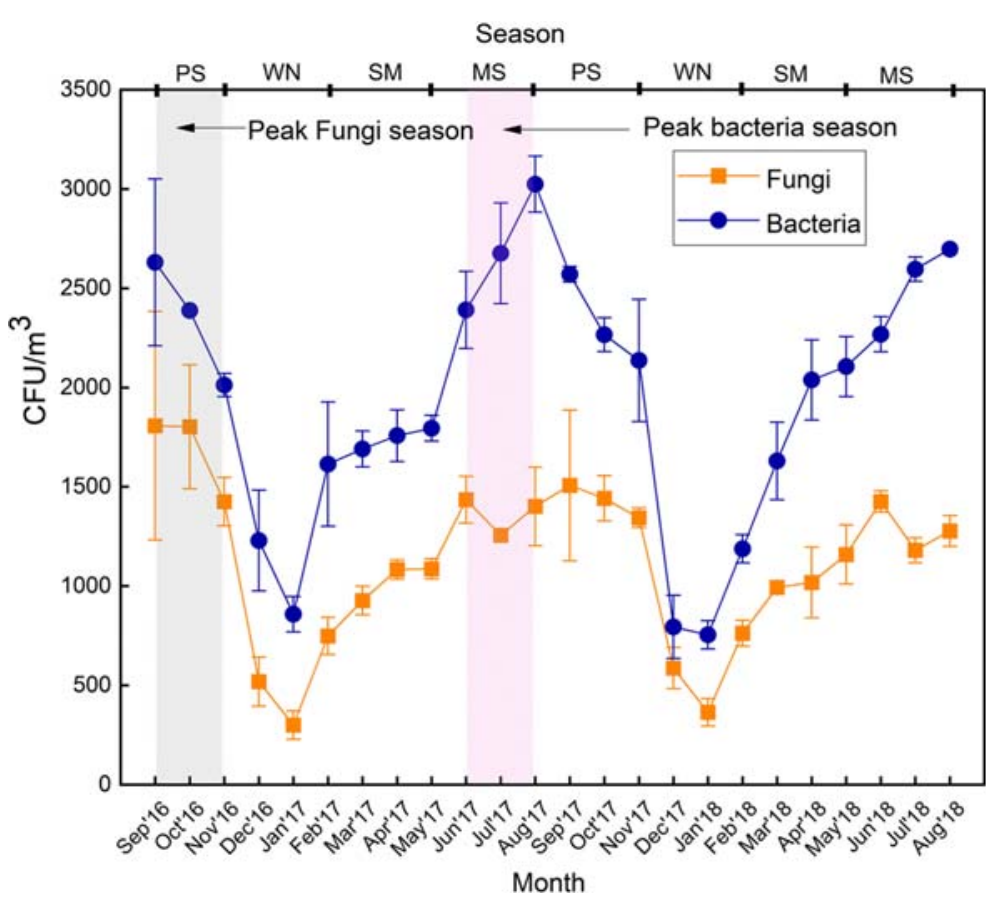

altitudes during rain events (Heo et al. 2014) leading to increased concentration near the ground surface; (b) raindrop splash may induce microbial dislodging and aerosolization from the ground surface ( $\mathrm{Li}$ et al. 2017; Lee 2011); (c) increase in humid conditions favors the bacterial growth, which is also evident from the significant positive correlation observed between bacterial bioaerosols and relative humidity $(r=0.64, p<0.05)$. In the subsequent months of July and August, the fungal concentration decreased substantially, while the bacterial concentration showed an increasing trend. The observed results can be explained as follows: Fan et al. (2017) reported soil as a major source of fungal introduction in ambient air. However, as the soil moisture is high during the late monsoonal months, the fungal resuspension from ground decreased due to rainfall facilitated wet scavenging. This phenomenon is also mentioned in Rathnayake et al. (2017). On the other hand, the impact of wet sedimentation in bacteria was lower than fungi because of their comparatively smaller

Table 2 Mean value of meteorological parameters, vehicle count and mean concentrations of $\mathrm{PM}_{1}, \mathrm{PM}_{2.5}$, and $\mathrm{PM}_{10}$ during different seasons

\begin{tabular}{lllll}
\hline Parameters & Monsoon & Post monsoon & Winter & Summer \\
\hline Temperature $\left({ }^{\circ} \mathrm{C}\right)$ & $29.9 \pm 2.0$ & $26.6 \pm 4.5$ & $17.0 \pm 2.7$ & $30.1 \pm 5.2$ \\
Rainfall $(\mathrm{mm})$ & $8.48 \pm 11.67$ & - & $0.27 \pm 0.95$ & - \\
Relative humidity $(\%)$ & $74.6 \pm 19.2$ & $55.5 \pm 5.1$ & $42.4 \pm 11.9$ & $36.5 \pm 8.6$ \\
Solar radiation $\left(\mathrm{W} / \mathrm{m}^{2}\right)$ & $549.03 \pm 90.38$ & $470.48 \pm 69.55$ & $357.85 \pm 69.75$ & $596.41 \pm 64.71$ \\
PBLH $(\mathrm{m})$ & $597.74 \pm 566.17$ & $333.81 \pm 126.81$ & $332.37 \pm 218.52$ & $890.96 \pm 520.1$ \\
Wind speed $(\mathrm{m} / \mathrm{s})$ & $2.21 \pm 0.79$ & $1.24 \pm 0.61$ & $1.71 \pm 0.81$ & $2.42 \pm 1.13$ \\
Per hour vehicle count & $196 \pm 14$ & $197 \pm 8$ & $155 \pm 7$ & $158 \pm 11$ \\
PM $\left(\mu \mathrm{g} / \mathrm{m}^{3}\right)$ & $8.9 \times 10^{1} \pm 5.3$ & $1.2 \times 10^{2} \pm 1.0 \times 10^{1}$ & $6.8 \times 10^{1} \pm 1.4 \times 10^{1}$ & $7.5 \times 10^{1} \pm 1.1 \times 10^{1}$ \\
PM & & & & \\
PM $_{10}\left(\mu \mathrm{g} / \mathrm{m}^{3}\right)$ & $1.1 \times 10^{2} \pm 7.7$ & $1.5 \times 10^{2} \pm 1.7 \times 10^{1}$ & $9.5 \times 10^{1} \pm 1.2 \times 10^{1}$ & $1.0 \times 10^{2} \pm 7.7$ \\
Total airborne particles $\left(\mathrm{pts} / \mathrm{m}^{3}\right)$ & $1.4 \times 10^{6} \pm 4.9 \times 10^{5}$ & $2.0 \times 10^{6} \pm 5.3 \times 10^{5}$ & $1.5 \times 10^{6} \pm 2.9 \times 10^{5}$ & $1.8 \times 10^{6} \pm 7.9 \times 10^{5}$ \\
\hline
\end{tabular}


Table 3 Pearson correlation coefficient between bioaerosol and PM concentration, meteorological parameters (TP: temperature, RF: rainfall, RH: relative humidity, WS: wind speed, SR: solar radiation, PBLH: planetary boundary layer height), and $\mathrm{VC}$ : vehicular count

\begin{tabular}{llcrlr}
\hline & Bacteria & Fungi & $\mathrm{PM}_{1}$ & $\mathrm{PM}_{2.5}$ & $\mathrm{PM}_{10}$ \\
\hline Bacteria & 1 & & & & \\
Fungi & $0.83^{*}$ & 1 & & & \\
$\mathrm{PM}_{1}$ & $0.60^{*}$ & $0.76^{*}$ & 1 & & \\
$\mathrm{PM}_{2.5}$ & $0.55^{*}$ & $0.72^{*}$ & $0.91^{*}$ & 1 & \\
$\mathrm{PM}_{10}$ & $0.75^{*}$ & $0.87^{*}$ & $0.82^{*}$ & 0.75 & 1 \\
$\mathrm{TP}$ & $0.70^{*}$ & $0.61^{*}$ & 0.26 & 0.17 & 0.48 \\
$\mathrm{RF}$ & $0.42^{*}$ & 0.15 & -0.03 & -0.12 & 0.16 \\
$\mathrm{RH}$ & $0.64^{*}$ & 0.37 & 0.13 & 0.08 & 0.03 \\
WS & 0.06 & -0.06 & -0.58 & $-0.58^{*}$ & -0.28 \\
SR & 0.49 & 0.48 & 0.05 & 0.09 & 0.25 \\
PBLH & 0.12 & 0.11 & -0.11 & -0.08 & 0.22 \\
VC & $0.81^{*}$ & $0.73^{*}$ & 0.58 & $0.42^{*}$ & 0.57 \\
${ }^{*} p<0.05$ & & & & &
\end{tabular}

aerodynamic size. Instead, the increase in bacterial concentration observed during late monsoonal months implies that the additional bacterial contribution from different sources is the more important factor influencing their distribution than the wet scavenging.

Vehicular count revealed a substantial rise in traffic flow; and hence the number of commuters, during monsoon and postmonsoon months. While wet deposition prevented ground-based aerosolization from traffic flow or human movement, elevated levels of bacterial aerosols in ambient air were possibly due to the release from the skin or respiratory expiration process of passersby. Fan et al. (2017) also reported that humans act as the direct source of bacterial emissions (from skin, body fluids and breathing) in crowded public spaces. A strong positive correlation between bacterial concentration and vehicle count (representing higher human movement) during monsoon season $(r=0.93, p<0.05)$ supports our results. During post monsoonal months (September to November), the redemption of dry conditions augmented the vehicular movement induced soil resuspension, which could be attributed to the corresponding increase in bioaerosol concentration. Again, this explanation is supported by the statistically significant correlation observed between bioaerosol concentrations and vehicle count during the study period $(r=0.81$ and 0.73 for bacteria and fungi, respectively) $(p<0.05)$.
The increased inflow of vehicles and travelers from July to October is due to the following reasons: (a) The study site observes high inflow of passersby; including students, office goers, job aspirants, and other private and government sector employees. This is because August marked the beginning of new session (after summer vacations) in their respective organizations. (b) The monsoonal and post monsoonal months also witness the commencement of a popular annual pilgrimage (Kanvar Yatra) where thousands of religious devotees march towards the holy city of Haridwar. ISBT acts as one of the important passing routes for the devotees arriving from the native and other states of the country.

No statistically significant correlation $(p>0.05)$ was observed between fungi and relative humidity. Further, both bacterial and fungal bioaerosols showed no significant relationship $(p>0.05)$ with the rest of the meteorological variables (i.e., wind speed, solar radiation, and PBLH) suggesting that their distribution at the study site is chiefly affected by nonmeteorological factors. The wind rose plot showing wind speed and wind direction at the study site during four seasons is represented in Appendix 9. The mean mass concentration of $\mathrm{PM}_{1}$, $\mathrm{PM}_{2.5}$, and $\mathrm{PM}_{10}$ for each season is shown in Table 2 . It was observed that the concentration of $\mathrm{PM}_{2.5}$ and $\mathrm{PM}_{10}$ exceeded the $24 \mathrm{~h}$ National Ambient Air Quality Standard (NAAQS, India) permissible limits of $60 \mu \mathrm{g} /$ $\mathrm{m}^{3}$ and $100 \mu \mathrm{g} / \mathrm{m}^{3}$, respectively, during the study period. The statistical analysis of airborne fungi and bacteria showed significant correlation with mass concentration of $\mathrm{PM}_{1}(r=0.76$ and 0.60 for fungi and bacteria, respectively), $\mathrm{PM}_{2.5}$ ( $r=0.72$ and 0.56 for fungi and bacteria, respectively), and $\mathrm{PM}_{10}(r=0.88$ and 0.75 for fungi and bacteria, respectively) $(p<0.05)$. This suggests that the variation of PM and bioaerosols can be linked to common sources of origin.

Particle size distribution and PM loading

The size-segregated concentration of the total cultivable, bacterial, and fungal aerosols at the study site are shown in Table 4. The maximum and minimum levels for fungi were reported at the aerodynamic size fractions > $7.0 \mu \mathrm{m}$ and $0.65-1.1 \mu \mathrm{m}$, respectively. Bacteria showed maximum concentration in $>7.0 \mu \mathrm{m}$ while minimum in $1.1-2.1 \mu \mathrm{m}$. Moreover, the coarse fraction $(>2.1 \mu \mathrm{m})$ dominated the bioaerosol size distribution $(83.36 \%$ for fungi and $82.85 \%$ for bacteria). The abundance of coarse particles in the roadside soil dust have been 
Table 4 Concentration of culturable bacteria and fungi $\left(\mathrm{CFU} / \mathrm{m}^{3} /\right.$ d $\log \mathrm{D}_{\mathrm{p}}$ ) in different size fractions

\begin{tabular}{llr}
\hline Size fraction & \multicolumn{1}{l}{ Fungi } & \multicolumn{1}{l}{ Bacteria } \\
\hline$>7.0 \mu \mathrm{m}$ & $725.97 \pm 297.77$ & $1211.44 \pm 393.69$ \\
$7.0-4.7 \mu \mathrm{m}$ & $593.96 \pm 243.28$ & $972.77 \pm 340.16$ \\
$4.7-3.3 \mu \mathrm{m}$ & $563.05 \pm 227.66$ & $1020.35 \pm 360.34$ \\
$3.3-2.1 \mu \mathrm{m}$ & $353.48 \pm 171.68$ & $700.73 \pm 245.61$ \\
$2.1-1.1 \mu \mathrm{m}$ & $226.54 \pm 108.06$ & $306.57 \pm 130.04$ \\
$1.1-0.65 \mu \mathrm{m}$ & $220.05 \pm 105.19$ & $501.88 \pm 209.17$ \\
\hline
\end{tabular}

reported by Ny and Lee (2010) and Clements et al. (2017) which can also be attributed for the elevated concentration of coarse size bioaerosol in our study site. At Mussoorie, $\sim 30 \mathrm{~km}$ from Dehradun city, vehicular movement was reported as the major factor influencing the PM levels in the ambient air (Sundriyal et al. 2018).

Figure 4 shows the size distribution of bioaerosols and total airborne particles at the study location. It was observed that the total particle number concentration for the aerodynamic size $<1.5 \mu \mathrm{m}$ is way higher than that for each larger aerodynamic diameter, indicating the abundance of fine particles in ambient air at the study site. The smaller size enhances the longevity of resuspension and the ability to penetrate the lower respiratory tract (Zukiewicz-Sobczak 2013; Fang et al. 2008).

The ratio between bioaerosol concentration and particle number concentration (PNC) $\left(\left(\mathrm{CFU} / \mathrm{m}^{3}\right) / \mathrm{d} \log \mathrm{Dp} /(\mathrm{dN} /\right.$ $\mathrm{dLogDp})$ ) at different aerodynamic size were calculated to estimate the bioaerosol loading in PM (Fig. 4). Here,
$\mathrm{dN}=$ particle number concentration (particles $/ \mathrm{m}^{3}$ ). Total fungal aerosols showed a $3.25 \%$ contribution in the total PM count while it was $5.65 \%$ for bacterial aerosols. The ratio at an aerodynamic size below $0.9 \mu \mathrm{m}$ approaches zero ( 0.0013 for fungi and 0.0026 for bacteria) which suggests that the bioaerosol loading of PM in submicron size fraction is lower compared to larger size fractions. The elevated microbial contribution in larger sized particles can be associated with the observations made by Lighthart (1997) and Raisi et al. (2013) who reported that the particles larger than the size of the single microbial cell can hold a greater share of microbial aerosol. Thus, while particle bound bioaerosols are majorly associated with larger particles, their ability to remain suspended as freely floating cells increases with the decrease in the aerodynamic diameter. Our study also revealed that the bacterial concentration in submicron size fraction was greater than fungal concentration. Therefore, a significant portion of airborne bacteria in this size range may be representing the freely distributed forms. Taking together, it can be assumed that besides the traffic and human movement induced soil and dust resuspension, the aerosolization of bacteria, chiefly in submicron size range may be occurring from other sources such as human respiratory system, microflora present in the human body, etc. Johnson et al. (2011) ascertained that the modality of human expired aerosols can be divided into a bronchiolar/laryngeal/oral (B.L.O.) tri-modal distribution during the speech, coughing and tidal breathing process. However, understanding the mechanism of microbial aerosolization, adhesion to atmospheric particulates, and distribution as
Fig. 4 Size distribution of airborne fungal, bacterial, and total airborne particles

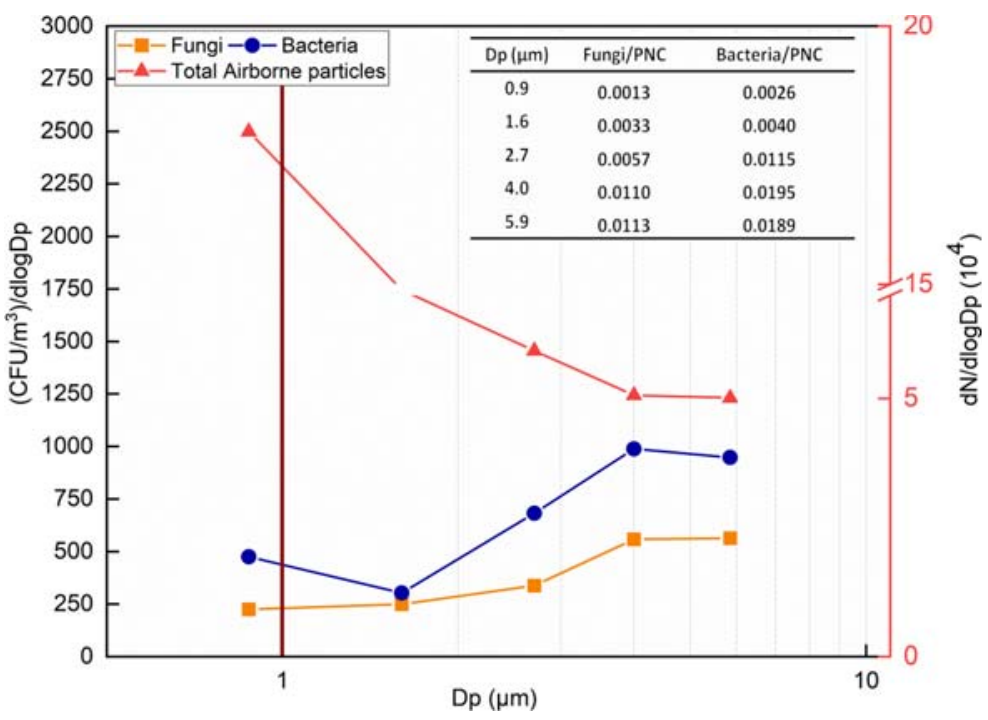


Table 5 Composition and percent contribution of airborne microbes at ISBT

\begin{tabular}{|c|c|c|c|c|c|}
\hline Fungi & No. of species & Percentage & Bacteria & No. of species & Percentage \\
\hline Aspergillus & 11 & 22 & Gram-positive bacteria & & \\
\hline Aspergillus fumigatus & & & Bacillus spp. & 7 & 17.07 \\
\hline Aspergillus ochraceus & & & Streptobacillus spp. & 5 & 12.19 \\
\hline Aspergillus niger & & & Staphylococcus spp. & 4 & 9.76 \\
\hline Aspergillus Carbonarious & & & Micrococcus spp. & 4 & 9.76 \\
\hline Aspergillus flavus & & & Palisade spp. & 2 & 4.88 \\
\hline Aspergillus clavatus & & & Streptococcus spp. & 2 & 4.88 \\
\hline Other Aspergillus spp. & 5 & & Total & 24 & 58.54 \\
\hline Curvularia & 3 & 6 & Gram-negative bacteria & & \\
\hline Alternaria & 9 & 18 & Bacillus spp. & 5 & 12.19 \\
\hline Alternaria solani & & & Streptobacillus spp. & 3 & 7.32 \\
\hline Alternaria alternate & & & Vibrio spp. & 3 & 7.32 \\
\hline Other Alternaria spp. & 7 & & Diplobacillus spp. & 1 & 2.44 \\
\hline Rhizopus & 7 & 14 & Coccus spp. & 4 & 9.76 \\
\hline Rhizopus stolonifer & & & Spirillum spp. & 1 & 2.44 \\
\hline Other Rhizopus spp. & 6 & & Total & 17 & 41.46 \\
\hline Penicillium & 8 & 16 & Grand total & 41 & \\
\hline \multicolumn{6}{|l|}{ Penicillium marneffei } \\
\hline \multicolumn{6}{|l|}{ Penicillium chrysogenum } \\
\hline Other Penicillum spp. & 6 & & & & \\
\hline Cladosporium & 4 & 8 & & & \\
\hline \multicolumn{6}{|l|}{ Cladosporium herbarum } \\
\hline Other Cladosporium spp. & 3 & & & & \\
\hline Mucor spp. & 5 & 10 & & & \\
\hline Sterile mycelium & 2 & 4 & & & \\
\hline Trichoderma spp. & 1 & 2 & & & \\
\hline Total & 50 & & & & \\
\hline
\end{tabular}

freely moving or particle-bound aerosols is beyond the scope of this paper. The longevity, viability, and infectivity of microorganisms in the atmosphere are significantly affected by their association with PM. Understanding this association is important especially in the heavily crowded areas such as bus stations, railway platforms, religious places, etc. where people gather in close proximity to each other and may initiate the anthroponotic (person to person transmission) transfer of microbial infections. Johnson et al. (2011) showed that the transmission of severe acute respiratory syndrome (SARS) can be associated with proximity to infected individuals at a distance of $1 \mathrm{~m}$. Therefore, more research is needed to calculate the relative contribution of both the freely moving or attached forms in total bioaerosol concentration at the crowded public places.
Bioaerosol structure

The composition and percent contribution of airborne microbes at the study site are shown in Table 5. Overall, 41 bacterial isolates were identified from the results of microscopic and biochemical examinations. These accounted for $58.5 \%$ gram-positive and $41.5 \%$ gramnegative bacteria. The gram-positive bacteria dominated the distribution, wherein Bacillus (17.10\%), Streptobacillus (12.20\%), Staphylococcus (9.76\%), and Micrococcus $(9.76 \%)$ accounted for approximately $50 \%$ of the total microbial diversity. With respect to fungi, 50 genera were identified after microscopic and macroscopic observations. Among the total fungi detected, the dominant genera were identified as Aspergillus (22\%), Alternaria (18\%), Penicillium (16\%), and Rhizopus (14\%). 
The relative abundance of bioaerosol distribution during different seasons is represented in Table 6. The mean relative abundance of the fungal variants in all four seasons followed the order: Aspergillus (27.6\%) > Penicillium (23.0\%) > Cladosporium $(14.1 \%)>$ Rhizopus $(9.6 \%)$. One of the major reasons for the elevated levels of Aspergillus and Penicillium can be attributed to their small and dry conidial spores which facilitate their atmospheric introduction and dispersion even under the conditions of low wind speed. These two genera were also reported by Hernández-Castillo et al. (2014) as the most abundant groups in the outdoor environment of busy subway stations in Mexico city. Alananbeh et al. (2015) also observed that Aspergillus contributed maximum to the total observed microflora in a crowded pilgrimage location in Al-Madina, Saudi Arabia. These results suggest that the commuters play a substantial role as the source of fungal aerosols in the ambient air of crowded public places. The pathogenic impact of these bioaerosols on the respiratory system has been reported in previous studies (Hernández-Castillo et al. 2014; Patil and Kakde 2017; Santos et al. 2006). Therefore, the abundance of these bioaerosols at our study site indicates the intensity of its human health vulnerability.

With respect to bacteria; gram-positive bacteria, including Micrococcus (25.7\%), Staphylococcus (17.9\%), and Bacillus (13.8\%) were the most prevalently distributed variants in all the four seasons. The gram-positive species are predominantly found in soil and in skin, hair, mucosa, arms, mouth, etc. of humans (Faridi et al. 2015; Mentese et al. 2012). Therefore, roadside soil and dust resuspension caused by traffic flow and human-associated activities can be attributed to the relative abundance of gram-positive bacteria at the sampling location. Also, high resistance of gram-positive bacteria towards adverse environmental conditions such as desiccation and solar radiation can lead to its predominance. The prolong viability of grampositive bacilli may be due to their ability to form desiccation tolerant spores (Shaffer and Lighthart 1997), while gram positive cocci survive by means of pigment formation (Hurtado et al. 2014).

Though spitting is prohibited in public spaces, during our study, we observed people spitting in public and this situation was more severe in public places including the

Table 6 Relative abundance of bioaerosol distribution during different seasons

\begin{tabular}{|c|c|c|c|c|c|}
\hline & Monsoon & Postmonsoon & Winter & Summer & Mean \\
\hline \multicolumn{6}{|l|}{ Fungi } \\
\hline Aspergillus & 29.6 & 25.3 & 21.3 & 34.1 & 27.58 \\
\hline Penicillium & 15.8 & 25.4 & 24.7 & 26.1 & 23 \\
\hline Alternaria & 12.4 & 7.4 & 6.7 & 10.3 & 9.2 \\
\hline Rhizopus & 9.5 & 10.7 & 8.4 & 10.1 & 9.68 \\
\hline Cladosporium & 15.4 & 16.5 & 15.2 & 9.1 & 14.05 \\
\hline Curvularia & 4.8 & 5.5 & 8.2 & 1.2 & 4.93 \\
\hline Mucor & 6.7 & 3.4 & 7.3 & 4.6 & 5.5 \\
\hline Sterile mycelium & 3.0 & 4.2 & 3.4 & 2.6 & 3.31 \\
\hline Trichoderma & 2.8 & 1.6 & 4.8 & 1.9 & 2.78 \\
\hline \multicolumn{6}{|c|}{ Gram-positive bacteria } \\
\hline Micrococcus & 23.1 & 37.6 & 21.7 & 20.5 & 25.73 \\
\hline Staphylococcus & 16.3 & 24.6 & 18.2 & 12.8 & 17.98 \\
\hline Bacillus & 14.2 & 7.2 & 16.5 & 17.3 & 13.8 \\
\hline Palisade & 9.7 & 5.6 & 6.8 & 5.3 & 6.85 \\
\hline Streptococcus & 9.1 & 2.6 & 2.8 & 5.8 & 5.08 \\
\hline \multicolumn{6}{|c|}{ Gram-negative bacteria } \\
\hline Bacillus & 11.5 & 12.5 & 16.3 & 12.9 & 13.3 \\
\hline Vibrio & 8.4 & 3.2 & 9.2 & 5.2 & 6.5 \\
\hline Coccus & 5.6 & 4.8 & 5.9 & 11.6 & 6.98 \\
\hline Spirillum & 2.1 & 1.9 & 2.6 & 8.6 & 3.8 \\
\hline
\end{tabular}


ISBT. The upper respiratory tract and oral cavity in humans is an important source of various pathogenic microbial strains (Hurtado et al. 2014). Therefore, when an infected person coughs or sneezes, he/she may release pathogenic bioaerosols into the surrounding air and may also infect those in close proximity. In a study conducted by Tiwari et al. (2010), statistically significant clusters of tuberculosis were reported at many places in Dehradun city. This study and our findings suggest that the high traffic density zone at ISBT can be categorized under increased risk of exposure to pathogenic bioaerosols. With the current pace of urbanization, the continuous increment in traffic flow and population density is expected to increase the frequency of traffic jams and road congestion. The corresponding increase in the waiting time of passengers is indicative of a longer exposure period. This implicates that the study site is under high threat of turning into a prospective source of epidemic disease outbreaks. This also shows the significance of bioaerosol monitoring in similarly crowded traffic intersections in other cities around the world.

\section{Conclusions}

This study investigated the temporal distribution of airborne cultivable bioaerosols and the factors affecting their variation at a high traffic density site. The major findings of this study are highlighted below:

1. The bacteria and fungi concentrations were highest during the monsoon and postmonsoon months, respectively. Major factors influencing the distribution were observed to be ground-based microbial aerosolization caused by raindrop splash, microbial discharge from humans (respiratory system and human body surface), elevated levels of relative humidity, and soil resuspension caused by vehicular and human movement.

2. Although both fungi and bacteria contributed majorly to coarse PM, bacterial aerosols also showed increased concentration in submicron size fractions, indicating a potential additional contribution from the human body (viz.) through breathing, coughing or talking). This implicates that there are increased chances of bacteriainduced anthroponosis owing to the high proximity between visitors at the sampled location.

3. The dominantly observed bioaerosols including $A s-$ pergillus, Penicillium, Cladosporium, Micrococcus,
Staphylococcus, and Bacillus are the potential pathogens for respiratory ailments such as aspergillosis, asthma, rhinosinusitis, and various other pulmonary infections.

4. Since high vehicle count and human activities were identified as the factors that masked the effects of microclimatic conditions, the results from this study site can be generalized for other similar crowded traffic areas. Moreover, observations showed that the traffic junctions are one of the key initiation points for the transmission of various communicable diseases and therefore can be studied to trace the source of microbial infections during the epidemic disease outbreaks.

For the safety of the passengers, biodefense strategies can be developed to prevent/minimize their direct exposure to microbial pathogens. This may include the use of real-time bioaerosol detection technologies to alarm commuters and recommending passenger safety plans such as placing color-coded air quality display screens showing level of pollution, recommending alternate routes of travel, regularizing the use of face masks, conducting awareness programs on personal and environmental hygiene, and preventing littering and spitting in public places through strict laws. As the study was limited only to cultivable bioaerosols, assessment of noncultivable forms along with dose-response relationship is required to document the precise extent and impact of bioaerosol pollution in such heavily crowded regions.

Acknowledgments The authors would like to thank Dr. Kusum Arunachalam, Head of Department, School of Environment and Natural Resources (SENR), Doon University, for providing laboratory facilities and permission to carry out the study. DST FIST scheme support to SENR for Grimm Mini - WRAS instrument is highly acknowledged.

\section{References}

Abdel Hameed, A. A., Khoder, M. I., Yuosra, S., Osman, A. M., \& Ghanem, S. (2009). Diurnal distribution of airborne bacteria and fungi in the atmosphere of Helwan area, Egypt. Science of the Total Environment, 407(24), 6217-6222. https://doi. org/10.1016/j.scitotenv.2009.08.028.

Akpeimeh, G. F., Fletcher, L. A., \& Evans, B. E. (2019). Exposure to bioaerosols at open dumpsites: A case study of bioaerosols 
exposure from activities at Olusosun open dumpsite, Lagos Nigeria. Waste Management, 89, 37-47. https://doi. org/10.1016/j.wasman.2019.03.058.

Alananbeh, K. M., Boquellah, N., Al Kaff, N., \& Ahmadi, M. A. (2015). Evaluation of aerial microbial pollutants in Al-Haram Al-Nabawi during pilgrimage of 2013. Saudi Journal of Biological Sciences, 24, 217-225. https://doi.org/10.1016/j. sjbs.2015.08.003.

Barnett, H., \& Hunter, B. (2010). Illustrated genera of imperfect fungi. St. Paul: APS Press The American Phytopathological Society.

Chi, M. C., \& Li, C. S. (2007). Fluorochrome in monitoring atmospheric bioaerosols and correlations with meteorological factors and air pollutants. Aerosol Science and Technology, 41(7), 672-678. https://doi.org/10.1080/02786820701383181.

Clements, A. L., Fraser, M. P., Upadhyay, N., Herckes, P., Sundblom, M., Lantz, J., \& Solomon, P. A. (2017). Source identification of coarse particles in the Desert Southwest, USA using positive matrix factorization. Atmospheric Pollution Research, 8(5), 873-884. https://doi.org/10.1016 /j.apr.2017.02.003.

Connor, D. J. O., Daly, S. M., \& Sodeau, J. R. (2015). On-line monitoring of airborne bioaerosols released from a composting / green waste site. Waste Management, 42, 2330. https://doi.org/10.1016/j.wasman.2015.04.015.

Cordeiro, R. A., Brilhante, R. S., Pantoja, L. D., Moreira Filho, R. E., Vieira, P. R., Rocha, M. F., Monteiro, A. J., \& Sidrim, J. J. (2010). Isolation of pathogenic yeasts in the air from hospital environments in the city of Fortaleza, Northeast Brazil. Brazilian Journal of Infectious Diseases, 14(1), 30-34. https://doi.org/10.1590/S1413-86702010000100007.

Dales, R. E., Cakmak, S., Judek, S., Dann, T., Coates, F., Brook, J. R., \& Burnett, R. T. (2004). Influence of outdoor aeroallergens on hospitalization for asthma in Canada. Journal of Allergy and Clinical Immunology, 113(2), 303306. https://doi.org/10.1016/j.jaci.2003.11.016.

Das, S., \& Kataria, V. (2011). Bioterrorism : A public health perspective. Medical Journal, Armed Forces India, 66(3), 255-260 10.1016/s0377-1237(10)80051-6.

Després, V. R., Alex Huffman, J., Burrows, S. M., Hoose, C., Safatov, A. S., Buryak, G., et al. (2012). Primary biological aerosol particles in the atmosphere: A review. Tellus Series B: Chemical and Physical Meteorology, 64(1). https://doi. org/10.3402/tellusb.v64i0.15598.

Dong, S., \& Yao, M. (2010). Exposure assessment in Beijing, China: Biological agents, ultrafine particles, and lead. Environmental Monitoring and Assessment, 170(1-4), 331343. https://doi.org/10.1007/s10661-009-1236-7.

Dybwad, M., Skogan, G., \& Blatnya, J. M. (2014). Temporal variability of the bioaerosol background at a subway station: Concentration level, size distribution, and diversity of airborne bacteria. Applied and Environmental Microbiology, 80(1), 257-270. https://doi.org/10.1128/AEM.02849-13.

Erkara, I. P., Asan, A., Yilmaz, V., Pehlivan, S., \& Okten, S. S. (2008). Airborne Alternaria and Cladosporium species and relationship with meteorological conditions in Eskisehir City, Turkey. Environmental Monitoring and Assessment, 144(13), 31-41. https://doi.org/10.1007/s10661-007-9939-0.

Fan, H., Li, X., Deng, J., Da, G., Gehin, E., \& Yao, M. (2017). Time-dependent size-resolved bacterial and fungal aerosols in Beijing subway. Aerosol and Air Quality Research, 17, 799-809. https://doi.org/10.4209/aaqr.2016.03.0114.

Fang, Z., Ouyang, Z., Zheng, H., Wang, X., \& Hu, L. (2005). Culturable airborne bacteria in outdoor environments in Beijing, China. Microbial Ecology, 54(3), 487-496. https://doi.org/10.1007/s00248-007-9216-3.

Fang, Z., Ouyang, Z., Zheng, H., \& Wang, X. (2008). Concentration and size distribution of culturable airborne microorganisms in outdoor environments in Beijing, China. Aerosol Science and Technology, 42(5), 325-334. https://doi. org/10.1080/02786820802068657.

Faridi, S., Hassanvand, M. S., Naddafi, K., Yunesian, M., Nabizadeh, R., Sowlat, M. H., Kashani, H., Gholampour, A., Niazi, S., Zare, A., Nazmara, S., \& Alimohammadi, M. (2015). Indoor/outdoor relationships of bioaerosol concentrations in a retirement home and a school dormitory. Environmental Science and Pollution Research, 22(11), 8190-8200. https://doi.org/10.1007/s11356-014-3944-y.

Fröhlich-Nowoisky, J., Kampf, C. J., Weber, B., Huffman, J. A., Pöhlker, C., Andreae, M. O., et al. (2016). Bioaerosols in the Earth system: Climate, health, and ecosystem interactions. Atmospheric Research, 182, 346-376. https://doi. org/10.1016/j.atmosres.2016.07.018.

Fung, F., \& Hughson, W. G. (2010). Health effects of indoor fungal bioaerosol exposure. Applied Occupational and Environmental Hygiene, 18(7), 535-544. https://doi. org/10.1080/10473220301451.

Han, Z. Y., Weng, W. G., \& Huang, Q. Y. (2013). Characterizations of particle size distribution of the droplets exhaled by sneeze. Journal of the Royal Society Interface, 10(88), 20130560. https://doi.org/10.1098/rsif.2013.0560.

Heo, K. J., Kim, H. B., \& Lee, B. U. (2014). Concentration of environmental fungal and bacterial bioaerosols during the monsoon season. Journal of Aerosol Science, 77, 31-37. https://doi.org/10.1016/j.jaerosci.2014.07.001.

Hernández-Castillo, O., Mugica-Álvarez, V., Castañeda-Briones, M. T., Murcia, J. M., García-Franco, F., \& Falcón Briseño, Y. (2014). Aerobiological study in the Mexico City subway system. Aerobiologia, 30(4), 357-367. https://doi. org/10.1007/s10453-014-9334-6.

Hoseini, M., Jabbari, H., Naddafi, K., Nabizadeh, R., Rahbar, M., Yunesian, M., \& Jaafari, J. (2013). Concentration and distribution characteristics of airborne fungi in indoor and outdoor air of Tehran subway stations. Aerobiologia, 29(3), 355-363. https://doi.org/10.1007/s10453-012-9285-8.

Hurtado, L., Rodríguez, G., López, J., Castillo, J. E., Molina, L., Zavala, M., \& Quintana, P. J. E. (2014). Characterization of atmospheric bioaerosols at 9 sites in Tijuana, Mexico. Atmospheric Environment, 96, 430-436. https://doi. org/10.1016/j.atmosenv.2014.07.018.

Iwasaka, Y., Shi, G. Y., Yamada, M., Kobayashi, F., Kakikawa, M., Maki, T., Naganuma, T., Chen, B., Tobo, Y., \& Hong, C. S. (2009). Mixture of Kosa (Asian dust) and bioaerosols detected in the atmosphere over the Kosa particles source regions with balloonborne measurements: Possibility of long-range transport. Air Quality, Atmosphere and Health, 2(29), 2938. https://doi.org/10.1007/s11869-009-0031-5.

Jensen Paul A., Schafer Millie P. (1998). Sampling and characterization of bioaerosols, NIOSH Manual of Analytical Methods. 
Jerez, S. B., Cheng, Y., \& Bray, J. (2014). Exposure of workers to dust and bioaerosol on a poultry farm. The Journal of Applied Poultry Research, 23(1), 7-14. https://doi.org/10.3382 japr.2012-00710.

Johnson, G. R., Morawska, L., Ristovski, Z. D., Hargreaves, M., Mengersen, K., Chao, C. Y. H., et al. (2011). Modality of human expired aerosol size distributions. Journal of Aerosol Science, 42(12), 839-851. https://doi.org/10.1016/j. jaerosci.2011.07.009.

Jones, A. M., \& Harrison, R. M. (2004). The effects of meteorological factors on atmospheric bioaerosol concentrations - a review. Science of the Total Environment, 326(1-3), 151180. https://doi.org/10.1016/j.scitotenv.2003.11.021.

Kim, K. Y., Ko, H. J., Kim, H. T., Kim, Y. S., Roh, Y. M., Lee, C. M., \& Kim, C. N. (2007). Monitoring of aerial pollutants emitted from swine houses in Korea. Environmental Monitoring and Assessment, 133(1-3), 255-266. https://doi. org/10.1007/s10661-006-9578-x.

Kowalski, M., \& Pastuszka, J. S. (2018). Effect of ambient air temperature and solar radiation on changes in bacterial and fungal aerosols concentrationin the urban environment. Annals of Agricultural and Environmental Medicine, 25(2), 259-261. https://doi.org/10.26444/aaem/75877.

Lee, B. U. (2011). Life comes from the air: A short review on bioaerosol control. Aerosol and Air Quality Research, 11(7), 921-927. https://doi.org/10.4209/aaqr.2011.06.0081.

Li, Y., Fu, H., Wang, W., Liu, J., Meng, Q., \& Wang, W. (2015). Characteristics of bacterial and fungal aerosols during the autumn haze days in Xi'an, China. Atmospheric Environment, 122, 439-447. https://doi.org/10.1016/j. atmosenv.2015.09.070.

Li, Y., Lu, R., Li, W., Xie, Z., \& Song, Y. (2017). Concentrations and size distributions of viable bioaerosols under various weather conditions in a typical semi-arid city of Northwest China. Journal of Aerosol Science. https://doi.org/10.1016/j. jaerosci.2017.01.007.

Lighthart, B. (1997). The ecology of bacteria in the alfresco atmosphere. FEMS Microbiology Ecology, 23(4), 263-274. https://doi.org/10.1111/j.1574-6941.1997.tb00408.x.

Madhwal, S., Prabhu, V., Sundriyal, S., \& Shridhar, V. (2019). Distribution, characterization and health risk assessment of size fractionated bioaerosols at an open landfill site in Dehradun, India. Atmospheric Pollution Research, 11(1), 156-169. https://doi.org/10.1016/j.apr.2019.10.002.

Matheson, M. C., Benke, G., Raven, J., Sim, M. R., Kromhout, H., Vermeulen, R., Johns, D. P., Walters, E. H., \& Abramson, M. J. (2005). Biological dust exposure in the workplace is a risk factor for chronic obstructive pulmonary disease. Thorax, 60(8), 645-651. https://doi.org/10.1136/thx.2004.035170.

Mentese, S., Rad, A. Y., Arisoy, M., \& Güllü, G. (2012). Seasonal and spatial variations of bioaerosols in indoor urban environments, Ankara, Turkey. Indoor and Built Environment, 21(6), 797-810. https://doi.org/10.1177/1420326X11425965.

Michałkiewicz, M. (2018). Comparison of wastewater treatment plants based on the emissions of microbiological contaminants. Environmental Monitoring and Assessment, 190(11), 640. https://doi.org/10.1007/s10661-018-7035-2.

Millner, P. D. (2009). Bioaerosols associated with animal production operations. Bioresource Technology, 100(22), 53795385 .
Nasir, Z. A., Colbeck, I., Sultan, S., \& Ahmed, S. (2012). Bioaerosols in residential micro-environments in low income countries: A case study from Pakistan. Environmental Pollution, 168, 15-22. https://doi.org/10.1016/j. envpol.2012.03.047

Ny, M. T., \& Lee, B. K. (2010). Size distribution and source identification of airborne particulate matter and metallic elements in a typical industrial city. Asian Journal of Atmospheric Environment, 4(1), 9-19. https://doi. org/10.5572/ajae.2010.4.1.009.

Oliveira, M., Ribeiro, H., Delgado, J. L., \& Abreu, I. (2009). The effects of meteorological factors on airborne fungal spore concentration in two areas differing in urbanisation level. International Journal of Biometeorology, 53(1), 61-73. https://doi.org/10.1007/s00484-008-0191-2.

Patil, N. S., \& Kakde, U. B. (2017). Assessment of fungal bioaerosol emission in the vicinity of a landfill site in Mumbai, India. International Journal of Environment and Waste Management, 20(1), 75. https://doi.org/10.1504 /IJEWM.2017.086031.

Pepeljnjak, S., \& Šegvić, M. (2003). Occurrence of fungi in air and on plants in vegetation of different climatic regions in Croatia. Aerobiologia, 19(1), 11-19. https://doi.org/10.1023 /A:1022693032075.

Ponce-Caballero, C., Gamboa-Marrufo, M., Lopez-Pacheco, M., Ceron-Palma, I., Quintal-Franco, C., Giacoman-Vallejos, G. and Loria-Arcilam, J.H. (2013). Seasonal variation of airborne fungal propagules indoor and outdoor of domestic environments in Mérida, Mexico. Atmosfera 26, 369-377. https://doi.org/10.1016/S0187-6236(13)71083-X.

Prabhu, V., \& Shridhar, V. (2019). Investigation of potential sources, transport pathway, and health risks associated with respirable suspended particulate matter in Dehradun city, situated in the foothills of the Himalayas. Atmospheric Pollution Research, 10(1), 187-196. https://doi.org/10.1016 j.apr.2018.07.009.

Prabhu, V., Gupta, S. K., Madhwal, S., \& Shridhar, V. (2019). Exposure to atmospheric particulates and associated respirable deposition dose to street vendors at the residential and commercial sites in Dehradun City. Safety And Health At Work (in press). https://doi.org/10.1016/j.shaw.2019.01.005.

Prussin, A. J., \& Marr, L. C. (2015). Sources of airborne microorganisms in the built environment. Microbiome, 3, 78. https://doi.org/10.1186/s40168-015-0144-Z.

Rahman, S. S., Siddique, R., \& Tabassum, N. (2017). Isolation and identification of halotolerant soil bacteria from coastal Patenga area. BMC Research Notes, 10(531), 4-9. https://doi.org/10.1186/s13104-017-2855-7.

Raisi, L., Aleksandropoulou, V., Lazaridis, M., \& Katsivela, E. (2013). Size distribution of viable, cultivable, airborne microbes and their relationship to particulate matter concentrations and meteorological conditions in a Mediterranean site. Aerobiologia, 29(2), 233-248. https://doi.org/10.1007 /s10453-012-9276-9.

Rashidi, S., Shahmoradi, B., Maleki, A., Sharafi, K., \& Darvishi, E. (2017). Density assessment and mapping of microorganisms around a biocomposting plant in Sanandaj, Iran. Environmental Monitoring and Assessment, 189(5), 233. https://doi.org/10.1007/s10661-017-5914-6.

Rathnayake, C. M., Metwali, N., Jayarathne, T., Kettler, J., \& Huang, Y. (2017). Influence of rain on the abundance of 
bioaerosols in fine and coarse particles. Atmospheric Chemistry and Physics, 17, 2459-2475. https://doi. org/10.5194/acp-17-2459-2017.

Santos, P. E., Piontelli, E., Shea, Y. R., Galluzzo, M. L., Holland, S. M., Zelazko, M. E., \& Rosenzweig, S. D. (2006). Penicillium piceum infection: Diagnosis and successful treatment in chronic granulomatous disease. Medical Mycology, 44(8), 749-753. https://doi.org/10.1080 13693780600967089 .

Shaffer, B. T., \& Lighthart, B. (1997). Survey of culturable airborne bacteria at four diverse locations in Oregon: Urban, rural, forest, and coastal. Microbial Ecology, 34, 167-177. https://doi.org/10.1007/s002489900046.

Srivastava, A., Singh, M., \& Jain, V. K. (2012). Identification and characterization of size-segregated bioaerosols at Jawaharlal Nehru University, New Delhi. Natural Hazards, 60(2), 485499. https://doi.org/10.1007/s11069-011-0022-3.

Sundriyal, S., Shridhar, V., Madhwal, S., Pandey, K., \& Sharma, V. (2018). Impacts of tourism development on the physical environment of Mussoorie, a hill station in the lower Himalayan range of India. Journal of Mountain Science, 15(10), 2276-2291. https://doi.org/10.1007/s11629-0174786-0.

Tiwari, N., Kandpal, V., Tewari, A., Rao, K. R. M., \& Tolia, V. S. (2010). Investigation of tuberculosis clusters in Dehradun city of India. Asian Pacific Journal of Tropical Medicine,
3(6), 486-490. https://doi.org/10.1016/S1995-7645(10 )60117-4.

Tortora, G. J., Funke, B. R., \& Case, C. L. (1989). Microbiology an introduction (3rd ed.p. 72). Redwood City: The Benjamin/ Cummings publishing company, Inc. 82-83, 162, 215-216.

WHO, 2016. Ambient air pollution 2016.

Xie, Z., Fan, C., Lu, R., Liu, P., Wang, B., Du, S., et al. (2018). Characteristics of ambient bioaerosols during haze episodes in China: A review. Environmental Pollution, 243, 19301942. https://doi.org/10.1016/j.envpol.2018.09.051.

Xu, Z., \& Yao, M. (2013). Monitoring of bioaerosol inhalation risks in different environments using a six-stage Andersen sampler and the PCR-DGGE method. Environmental Monitoring and Assessment, 185(5), 3993-4003. https://doi. org/10.1007/s10661-012-2844-1.

Zukiewicz-Sobczak, W. A. (2013). The role of fungi in allergic diseases. Postepy Dermatologii i Alergologii, 30(1), 42-45. https://doi.org/10.5114/pdia.2013.33377.

Zuraimi, M. S., Fang, L., Tan, T. K., Chew, F. T., \& Tham, K. W. (2009). Airborne fungi in low and high allergic prevalence child care centers. Atmospheric Environment, 43(15), 23912400. https://doi.org/10.1016/j.atmosenv.2009.02.004.

Publisher's note Springer Nature remains neutral with regard to jurisdictional claims in published maps and institutional affiliations. 